\title{
The effect of quercetin on oxidative DNA damage and myelosuppression induced by etoposide in bone marrow cells of rats*
}

\author{
Monika A. Papież \\ Department of Cytobiology, Faculty of Pharmacy, Jagiellonian University Medical College, Kraków, Poland
}

\begin{abstract}
There is increasing evidence for the existence of an association between the presence of etoposide phenoxyl radicals and the development of treatment-related acute myeloid leukemia (t-AML), which occurs in a few percent of patients treated with this chemotherapeutic agent. The most common side effect caused by etoposide is myelosuppression, which limits the use of this effective drug. The goal of the study was to investigate the influence of antioxidant querectin on myelosuppression and oxidative DNA damage caused by etoposide. The influence of quercetin and/or etoposide on oxidative DNA damage was investigated in LT-12 cell line and bone marrow cells of rats via comet assay. The effect of quercetin on myelosuppression induced by etoposide was invetsigated by cytological analysis of bone marrow smears stained with May-Grünwald-Giemsa stain. Etoposide caused a significant increase in oxidative DNA damage in bone marrow cells and LT-12 cell line in comparison to the appropriate controls. Quercetin significantly reduced the oxidative DNA damage caused by etoposide both in vitro and in vivo. Quercetin also significantly protected against a decrease in the percentage of myeloid precursors and erythroid nucleated cells caused by etoposide administration in comparison to the group treated with etoposide alone. The results of the study indicate that quercetin could be considered a protectively acting compound in bone marrow cells during etoposide therapy.
\end{abstract}

Key words: quercetin, etoposide, myelosuppression, oxidative DNA damage, comet assay

Received: 16 October, 2013; revised: 10 December, 2013; accepted: 22 Januray, 2014; available on-line: 17 March, 2014

\section{INTRODUCTION}

There is evidence of a relationship between oxidative stress and the occurrence of acute myeloid leukemia (Battisti et al., 2008). Oxidative stress coincides with an increased frequency of DNA damage, the presence of specific mutations and an decrease in antioxidant capacity in patients with AML (Sallmyr et al., 2008, Zhou et al., 2007, Zhou et al., 2010). The use of conventional chemotherapeutic agents may increase oxidative stress (Kasapović et al., 2010). This phenomenon has a favorable therapeutic effect in cancer cells, because strong oxidative stress can induce apoptosis of these cells (Feng et al., 2007). However, oxidative stress may be detrimental to normal proliferating cells, such as hematopoietic progenitor cells, and may lead to oxidative damage to macromolecules, including DNA damage.

One of the cytostatic drugs, from which phenoxyl radicals are formed in bone marrow cells, is etoposide (Haim et al., 1987). These radicals are likely to facilitate leukemogenesis, which occurs in a few percent of patients treated with this drug (Whitlock et al., 1991). They are formed in large quantities under the influence of the metabolic conversion of etoposide by myeloperoxidase. High levels of activity of this enzyme are detected in precursors of myeloid lineage (Kagan et al., 1999; Vlasova et al., 2011). It is possible that the development of t-AML could be prevented by limiting the amount of etoposide phenoxyl radicals.

The second serious side effect caused by etoposide is myelosuppression (Kobayashi \& Ratain, 1994), which limits its application and may be a cause of the failure of chemotherapy. Etoposide inhibits proliferation of cells in the G2/M phase of the cell cycle (Ishiyama et al., 1994). The development of bone marrow hypoplasia induced by etoposide could also partially be attributed to the pro-oxidant action of its radicals. Oxidation of thiol groups by etoposide phenoxyl radicals may lead to a decline in the level of glutathione and increased oxidative damage to DNA, which in turn contributes to the formation of DNA strand breaks (Kagan et al., 1999; Sallmyr et al., 2008). Such extensive damage in bone marrow progenitor cells can cause apoptosis or necrosis leading to bone marrow hypoplasia.

On the basis of the fact that etoposide side effects in bone marrow may correspond to the pro-oxidant action of this drug, appropriate antioxidant supplements could provide effective protection. One of such natural antioxidants are plant polyphenols, e.g. quercetin, which scavenging free radicals and chelating transition metal ions (Hu et al., 1995) could be effective in reducing toxic metabolites of etoposide.

Due to their low toxicity, polyphenols are not likely to potentiate the cytotoxic effects of this drug in normal cells. Moreover, another characteristic of these compounds is their selective cytotoxic activity in cancer cells and the lack of any such action or at least only minimal cytotoxicity in normal cells (Shammas et al., 2006;

e-mail: monika.papiez@uj.edu.pl

${ }^{*}$ A preliminary report on the same subject was presented at 5 th Central European Congress of Life Sciences "EUROBIOTECH 2013" Kraków, Poland.

Abbreviations: $\mathrm{t}-\mathrm{AML}$, treatment-related acute myeloid leukemia; 8-OH-dG, 7,8-dihydro-8-oxoguanosine 
Feng et al., 2007). Limitation of myelosuppression and the genotoxic action of etoposide in normal cells could enable an increase in etoposide dosages and improve the effectiveness of this chemotherapeutic drug.

Other studies have shown that quercetin may protect cells against induced DNA damage (Wilms et al., 2005; Kapiszewska et al., 2007). The aim of the present study was to determine the influence of quercetin on oxidative DNA damage and myelosuppression caused by etoposide.

\section{MATERIAL AND METHODS}

Chemicals. Quercetin, etoposide, normal and low melting point (LMPA) agarose, triton-X-100, ethylenediamine tetraacetc acid disodium salt (EDTA) and formamidopyrimidine-DNA glycosylase (Fpg) were acquired from Sigma-Aldrich Co. (St. Louis, Missouri, USA). Dimethyl sulfoxide (DMSO) was from POCH (Poland). The medium (RPMI 1640), serum (FBS), phosphatebuffered saline (PBS) were purchased from PAA (Pasching, Austria).

Cell culture and treatment. Brown Norway rat promyelocytic leukemia LT12 cell line (a generous gift from Professor A.C.M. Martens, Utrecht) was cultured in RPMI 1640 supplemented with $10 \%$ FCS, without antibiotics. Cells were incubated at $37^{\circ} \mathrm{C}$ in a $5 \% \quad \mathrm{CO}_{2}$ and $95 \%$ humidified atmosphere and kept in the logarithmic growth phase. The cells were seeded in 24-well culture plates at a density of $0.5 \times 10^{6}$ cells $/ \mathrm{ml}$ and incubated in the presence of different concentrations of quercetin $(1-20 \mu \mathrm{M})$ and/or etoposide $(5 \mu \mathrm{M})$ for 1-24 hours. Compounds were dissolved in DMSO in PBS. Final concentrations of DMSO did not exceed $1 \% \mathrm{DMSO} / \mathrm{ml}$ in culture medium. Control cells were incubated only in the presence of DMSO. The experiment was repeated two times.

Animals. Three-month-old male Brown Norway (BN/CrlCmd) rats were obtained from the Animal Center, Polish Academy of Sciences Medical Research Center (Warsaw, Poland). The animals were housed in plastic cages and maintained under standard conditions of $22^{\circ} \mathrm{C}$ and $50-60 \%$ humidity, with a 12 -h light-dark cycle. They had free access to water and a synthetic pellet diet without plant polyphenols (Morawski Label Feed, Kcynia, Poland). The experiments were performed in accordance with legal requirements, under a licence granted by the Jagiellonian University Commission of Ethics.

Treatment with quercetin and etoposide. After a two-week period of adaptation, the rats were divided into four groups of six animals each. Quercetin (with 0.5 $\mathrm{ml}$ of corn oil as a vehicle) was administered via oral gavage at a dose of $100 \mathrm{mg} / \mathrm{kg}$ b.w. for 14 consecutive days. The dose of quercetin was selected based on studies in which this polyphenol influenced the redox state in rat tissues (Choi et al., 2003). Etoposide was administered intraperitoneally for 3 consecutive days at a dose of $50 \mathrm{mg} / \mathrm{kg}$ b.w. This method of administration of etoposide is similar to treatment regimens used in some cancer patients. The amount of etoposide designed for one rat was dissolved in $50 \mu \mathrm{l}$ DMSO and $1.5 \mathrm{ml}$ of sterile PBS. The dose of etoposide was selected according to studies in which this cytostatic drug caused severe damage to DNA in the bone marrow of mice (Turner et al., 2001). The last experimental group was pretreated with quercetin for 11 days followed by co-administration of etoposide for the last 3 days of the experiment. Control rats were given vehicles for the investigated compounds.
Isolation of bone marrow cells. The rats were killed by cervical dislocation under vetbutal anaesthesia $2 \mathrm{~h}$ after the final quercetin dose and $1 \mathrm{~h}$ after the last dose of etoposide administration. The right femurs were excised immediately after euthanasia and smears were prepared form bone marrow using a small paintbrush moistened with FBS. Bone marrow from the left femurs was flushed with $1 \mathrm{ml}$ FBS into a tube precoated with EDTA and washed once in PBS $\left(230 \times \mathrm{g}, 10 \mathrm{~min}, 4^{\circ} \mathrm{C}\right)$. Then, the cell suspension was prepared in PBS and used in a comet assay.

Measurements of oxidative DNA damage using an alkaline comet assay. The extent of DNA damage was determined via alkaline single cell gel electrophoresis according to Tice et al. (1991). Briefly, $5 \mu \mathrm{l}$ of cells in PBS was mixed with $75 \mu \mathrm{l}$ of $0.5 \%$ low melting point agarose. The mixture was pipetted into slides precoated with $0.5 \%$ normal melting point agarose, covered with a coverglass and put on ice for 5 minutes. Then, the slides were incubated in freshly prepared lysis buffer $(2.5 \mathrm{M}$ $\mathrm{NaCl}, 100 \mathrm{mM}$ EDTA, $10 \mathrm{mM}$ Tris, $\mathrm{pH} 10.0$ and $1 \%$ Triton X-100, 10\% DMSO) for $24 \mathrm{~h}$ at $4^{\circ} \mathrm{C}$. Next, the slides were washed three times with an enzyme buffer (0.04 M of Hepes, $0.1 \mathrm{M}$ of KCL, $0.5 \mathrm{mM}$ of EDTA, and $0.2 \mathrm{mg} / \mathrm{mL}$ of bovine serum albumin; $\mathrm{pH} 8.0)$ and incubated in enzyme buffer for 30 minutes at $37^{\circ} \mathrm{C}$ with $1 \mathrm{U} /$ slide of Fpg, which cut the oxidized purine bases. Control slides were incubated with enzyme buffer only. The slides were then placed in a horizontal electrophoresis tank containing fresh electrophoresis buffer (300 $\mathrm{mM} \mathrm{NaOH}, 1 \mathrm{mM}$ EDTA, $\mathrm{pH}$ 13) and incubated for 40 $\min$ at $4^{\circ} \mathrm{C}$. Electrophoresis was conducted for $30 \mathrm{~min}$ at $0.74 \mathrm{~V} / \mathrm{cm}$ and $300 \mathrm{~mA}$. The slides were washed with Tris/HCL, pH 7.5 and stained with propidium iodide $(2.5 \mu \mathrm{g} / \mathrm{ml})$. Comets were analyzed using a fluorescence microscope (Olympus CX-40; Olympus, Tokyo, Japan). An image system (The Comet Score ${ }^{\mathrm{TM}}$ image analysis system, TriTek Corporation, Sumerduck, Virginia, USA) was used for the measurement of the percentage of DNA in the tail of comets. Two slides per rat or well, with 100 randomly selected comets per slide, were analyzed.

Cytological evaluation of bone marrow. Smears were dried, stained using May-Grünwald-Giemsa stain and examined by counting approximately 500 cells/slide on three slides from each rat using an Olympus CX-40 microscope (Olympus, Tokyo, Japan).

Statistical analysis. Values were expressed as means \pm S.E.M. A one-way analysis of variance $(p<0.05)$ and Tukey post hoc test were used to determine significant differences between control and experimental samples.

\section{RESULTS}

\section{The level of oxidative DNA damage in the LT-12 cell line and rat bone marrow cells after treatment with quercetin and/or etoposide}

Etoposide, at a concentration of $5 \mu \mathrm{M}$, increased the level of oxidative damage to DNA in the LT-12 cell line after 1 and 24 hours of incubation. Pre-incubation with quercetin followed by cotreatment with etoposide significantly reduced the level of oxidative DNA damage compared to etoposide-only treated cells (Fig. 1). Incubation with quercetin alone at a concentration of 1-20 did not significantly affect the level of oxidative DNA damage (not shown). 


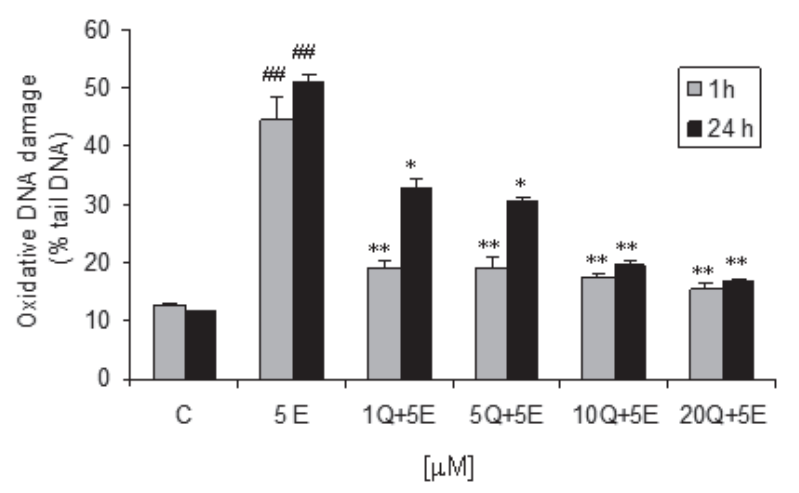

Figure 1. The extent of oxidative DNA damage induced by etoposide and/or querectin in LT-12 cells.

The cells were incubated for 1 and 24 hours with qurecetin and/ or etoposide. The oxidative DNA damage was measured in LT-12 cells by using comet assay. C - control, Q - quercetin, $\mathrm{E}$ - etoposide. $p^{*}<0.05$ vs. control, $p^{* *}<0.01$ vs. control, $p^{\#}<0.05$ vs. eto-

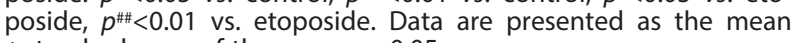
\pm standard error of the mean, $p<0.05$.

The administration of etoposide to the rats led to a significant increase in the level of oxidative DNA damage in the bone marrow cells in comparison to the control group. The use of quercetin before and during administration of etoposide resulted in a significant decrease in the level of oxidative DNA damage compared to etoposide alone. Quercetin did not exert a significant influence on the level of oxidative DNA damage in bone marrow cells compared to the control (Fig. 2).

\section{The influence of quercetin on the cytology of bone marrow in rats treated with etoposide}

Hypoplasia of the bone marrow was observed in the rats treated with etoposide. A significant decrease in the percentage of precursors of myeloid lineage, erythroid nucleated cells and a non-significant decrease in the

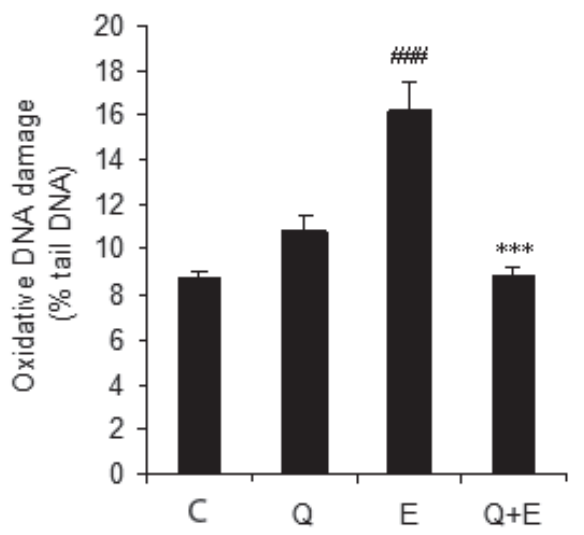

Figure 2. The extent of oxidative DNA damage induced by etoposide and/or querectin in rat bone marrow cells.

The rats were given quercetin at a dose of $100 \mathrm{mg} / \mathrm{kg}$ b.w. by gavage for 14 days. Etoposide was administered i.p. at a dose of $50 \mathrm{mg} / \mathrm{kg}$ b.w. for 3 consecutive days. The last group of experimental rats was administered with quercetin for 11 days followed by the coadministration of etoposide for the last 3 days of the experiment. Control group of rats was given solvent for examined compounds. The oxidative DNA damage was measured in the bone marrow cells by using comet assay. C - control, Q quercetin, $\mathrm{E}-$ etoposide. $p^{\# \#}<0.001$ vs. control, $p^{* * *}<0.001$ vs etoposide. Data are presented as the mean \pm standard error of the mean, $p<0.05$. percentage of lymphocytes was observed in comparison to the control. The predominant leukocytes in the bone marrow of rats treated with etoposide were mature granulocytes (Table 1).

The administration of quercetin before and during treatment with etoposide led to a reduction in bone marrow hypoplasia. A significant increase in the percentage of myeloid precursors (from myeloblast to metamyelocyte stages) and nucleated erythroid cells was observed after pre-treatment with quercetin followed by etoposide administration compared to etoposide alone. A clear, although non-significant, trend could be observed towards an increase in the percentage of lymphocytes in the group treated with quercetin and etoposide in comparison to the etoposide-only treated group. Quercetin alone did not exert any significant impact on the proportion of bone marrow cells (Table 1).

\section{DISCUSSION}

The likely reason for the leukemogenic action of etoposide is DNA damage in the precursor cells of the myeloid lineage caused by its phenoxyl radicals. It has been proved that a relationship exists between the formation of etoposide phenoxyl radicals and mixed-lineage leukemia (MLL) gene rearrangements in patients with $\mathrm{t}$ AML (Vlasova et al., 2011). Etoposide phenoxyl radicals can lead to oxidative DNA damage. One of the highly mutagenic oxidative lesions of DNA is 7,8-dihydro-8-oxoguanosine (8-OH-dG), elevated levels of which are detected in tumor cells (Irie et al., 2005), indicating its participation in carcinogenesis.

It can be assumed that quercetin as an antioxidant will scavenge phenoxyl radicals of etoposide and limit its pro-oxidant activity in myeloid pregenitor cells. The present study indirectly confirms this hypothesis, because pre-treatment with quercetin followed by etoposide significantly decreased the amount of oxidative damage to purine DNA bases induced by this chemotherapeutic agent in bone marrow cells of rats and rat myeloid LT12 cells. These results are consistent with other studies which have shown that quercetin protects human lymphocytes against oxidative DNA damage in vitro (Fabiani et al., 2001).

It should be noted that etoposide induced extensive oxidative DNA damage, which is consistent with the results obtained in previous studies (Papież, 2013).

Previous in vitro studies have also shown that quercetin inhibits the formation of etoposide phenoxyl radicals in human neutrophils and may protect the cells from apoptosis induced by etoposide at a concentration of $25 \mu \mathrm{M}$ (Kapiszewska et al., 2007). Hovewer, the present results suggest that pre-treatment with quercetin protects neutrophil precursors and other cells of the myeloid lineage against myelosuppressive effect of etoposide. Quercetin can thus protect neutrophils at various stages of their maturation. This protective effect was most marked within erythroid precursors and granulocytic lines, and restored the correct ratio of mature neutrophils to their precursors. It should be mentioned that in vitro studies have proven the protective effect of quercetin at a concentration of $1 \mu \mathrm{M}$ against genotoxic action of etoposide in neutrophils (Kapiszewska et al., 2007). However, the quercetin concentration in blood plasma of rats treated with $80 \mathrm{mg} / \mathrm{kg}$ b.w. of this flavonoid is $2.7 \mu \mathrm{M}$, (Papież et al., 2008).

Another studies has shown that quercetin administration to mice at a dosage of $50 \mathrm{mg} / \mathrm{kg}$ led to a decrease 
Table I. Percentage of hematopoetic cells isolated from bone marrow of rats.

\begin{tabular}{lllll}
\hline Group of rats & $\mathrm{C}$ & $\mathrm{Q}$ & $\mathrm{E}$ & $\mathrm{Q}+\mathrm{E}$ \\
\hline Myeloid precursors (\%) & $18.4 \pm 3.0$ & $11.6 \pm 1.2$ & $6.7 \pm 0.5^{* *}$ & $14.6 \pm 1.6^{\# \#}$ \\
\hline Mature granulocytes (\%) & $15.5 \pm 1.0$ & $12.6 \pm 3.2$ & $55.8 \pm 2.9^{* * *}$ & $15.6 \pm 6.9^{\# \#}$ \\
\hline Erythroid nucleated cells (\%) & $31.8 \pm 4.4$ & $23.2 \pm 3.5$ & $4.6 \pm 0.9^{* *}$ & $26.2 \pm 8.4^{\#}$ \\
\hline Lymphocytes (\%) & $12.5 \pm 2.6$ & $10.8 \pm 0.9$ & $8.3 \pm 3.0$ & $10.9 \pm 2.2$ \\
\hline
\end{tabular}

C, control rats, $\mathrm{Q}$, rats treated with quercetin $(100 \mathrm{mg} / \mathrm{kg}$ b.w.); $\mathrm{E}$, rats treated with etoposide (50 mg/kg b.w.). Data are presented as the mean

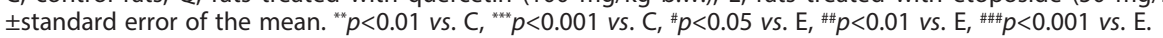

in the amount of chromosomal aberrations induced by methotrexate in bone marrow cells and diminished the number of cells with methotrexate-induced aberrations. In that study, quercetin also increased the mitotic index inhibited by methotrexate administration (Sekeroğlu \& Sekeroğlu, 2012). Other research has also shown that quercetin administered subcutaneously protected the bone marrow cells of rats against DNA double-strand breaks induced by etoposide (Kapiszewska et al., 2007). Similar results have been obtained in mice treated with topotecan, in which quercetin protected bone marrow cells against the geno- and cytotoxic action of this drug, while simultaneously raising the level of glutathione and reducing MDA levels in comparison to the cytostatic alone (Bakheet, 2011).

The results of the present study indicate that quercetin exerts an antioxidant rather than prooxidant effect, despite its potential ability to create toxic conjugates with -SH groups in vitro (Brisdelli et al., 2006). Quercetin-thiol conjugates can reduce the levels of glutathione, and interfere with the function of proteins and enzymes, such as endoplasmatic reticulum calcium ATPase, forming covalent complexes with them (Awad et al., 2002; Boots et al., 2007). The present results are in line with those other studies which have shown that quercetin acts as an antioxidant, protecting human chronic myeloid (K562) and acute lymphoblastic (HSB-2) leukemia cells from oxidative stress induced by tert-butylhydroperoxide (Brisdelli et al., 2006).

Etoposide phenoxyl radicals cause a decrease in glutathione in cells (Kagan et al., 1999) which may lead to oxidation of the mitochondrial membrane phospholipids, loss of integrity of this membrane and the induction of apoptosis. Quercetin, as an antioxidant, can scavenge etoposide phenoxyl radicals, protecting normal bone marrow cells of rats against apoptotic death induced by oxidative stress. Quercetin may also prevent the consequences of oxidative damage to DNA, which are DNA strand breaks leading to apoptosis or mutation (Sallmyr et al., 2008). Quercetin could also protect myeloid cells against the carcinogenic effect of etoposide by reducing the level of strong mutagen 8 -oxo-dG induced by this cytostatic drug. Further studies on the mechanism of quercetin action may be helpful in modifying the effect of etoposide treatment in normal bone marrow cells.

\section{Acknowledgements}

This study was supported by grant no. K/ ZDS/003318.

\section{REFERENCES}

Awad HM, Boersma MG, Boeren S, van der Woude H, van Zanden J, van Bladeren PJ, Vervoort J, Rietjens IM (2002) Identification of o-quinone/quinone methide metabolites of quercetin in a cellular in vitro system. FEBS Lett 520: 30-34
Bakheet SA (2011) Assessment of Anti-Cytogenotoxic Effects of Quercetin in Animals Treated with Topotecan. Oxid Med Cell Longev 2011: 1-8.

Battisti V, Maders LD, Bagatini MD, Santos KF, Spanevello RM, Maldonado PA, Brulé AO, Araújo Mdo C, Schetinger MR, Morsch VM (2008) Measurement of oxidative stress and antioxidant status in acute lymphoblastic leukemia patients. Clin Biochem 41: 511-528.

Boots AW, Li H, Schins RPF, Duffin R, Heemskerk JWM, Bast A, Haenen GRMM (2007) The quercetin paradox. Toxicol Appl Pharmacol 222: 89-96.

Brisdelli F, Coccia C, Cinque B, Cifone MG, Bozzi A (2007) Induction of apoptosis by quercetin: different response of human chronic myeloid (K562) and acute lymphoblastic (HSB-2) leukemia cells. Mol Cell Biochem 296: 137-149.

Choi EJ, Chee KM, Lee BH (2003) Anti- and prooxidant effects of chronic quercetin administration in rats. Eur J Pharmacol 482: 281285.

Fabiani R, De Bartolomeo A, Rosignoli P, Morozzi G (2001) Antioxidants prevent the lymphocyte DNA damage induced by PMA-stimulated monocytes, Nutr Cancer 39: 284-291.

Feng R, Ni HM, Wang SY, Tourkova IL, Shurin MR and Harada H (2007) Cyanidin-3-rutinoside, a natural polyphenol antioxidant, selectively kills leukemia cells by induction of oxidative stress. J Biol Chem 282: 13468-13476.

Haim N, Nemec J, Roman J, Sinha B (1987) Peroxidase-catalyzed metabolism of etoposide (VP-16-213) and covalent binding of reactive intermediates to cellular macromolecules. Cancer Res 47: 5835-5840.

Hu JP, Calomme M, Lasure A, De Bruyne T, Pieters L, Vlietinck A, Vanden Berghe DA (1995) Structure-activity relationships of flavonoids with superoxide scavenging ability. Boil. Trace Elem Res 47: 327-331.

Irie M, Miyata M, Kasai H (2005) Depression and possible cancer risk due to oxidative DNA damage. J Psychol Res 39: 553-60.

Ishiyama K, Satoh S, Igarashi Y, Kumagai H, Yahagi A, Sasaki H (1994) Flow cytometric analysis of the cell cycle of the leukemic cell lines treated with etoposide and cytosine arabinoside. Tohoku J Exp Med 174: 95-107.

Kagan VE, Yalowich JC, Borisenko GG, Tyurina YY, Tyurin VA, Thampatty P, Fabisiak JP (1999) Mechanism-based chemopreventive strategies against etoposide-induced acute myeloid leukemia: free radical/antioxidant approach. Mol Pharmacol 56: 494-506.

Kapiszewska M, Cierniak A, Papiez MA, Pietrzycka A, Stepniewski M, Lomnicki A (2007) Prolonged quercetin administration diminishes the etoposide-induced DNA damage in bone marrow cells of rats. Drug Chem Toxicol 30: 67-81.

Kasapović J, Pejić S, Stojiljković V, Todorović A, Radošević-Jelić L, Saičić ZS, Pajović SB (2010) Antioxidant status and lipid peroxidation in the blood of breast cancer patients of different ages after chemotherapy with 5-fluorouracil, doxorubicin and cyclophosphamide. Clin Biochem 43: 1287-1293.

Kobayashi K, Ratain MJ (1994) Pharmacodynamics and long-term toxicity of etoposide. Cancer Chemother Pharmacol 34: S64-S68.

Papież MA, Cierniak A, Krzyściak W, Bzowska M, Taha HM, Józkowicz A, Piskuła M. (2008) The changes of antioxidant defense system caused by quercetin administration do not lead to DNA damage and apoptosis in the spleen and bone marrow cells of rats. Food Chem Toxicol 46: 3053-3058.

Papież MA (2013) The influence of curcumin and (-)-epicatechin on the genotoxicity and myelosuppression induced by etoposide in bone marrow cells of male rats. Drug Chem Toxicol 36: 93-101.

Sallmyr A, Fan J, Rassool FV (2008) Genomic instability in myeloid malignancies: increased reactive oxygen species (ROS), DNA double strand breaks (DSBs), and error-prone repair. Cancer Lett 270: 1-9.

Sekeroglu ZA, Sekeroglu V (2012) Effects of Viscum album L. extract and quercetin on methotrexate-induced cyto-genotoxicity in mouse bone-marrow cells. Mutation Res 746: 56-59.

Shammas MA, Neri P, Koley H, Batchu RB, Bertheau RC, Munshi V, Prabhala R, Fulciniti MF, Tai YT, Treon SP, Goyal RK, Anderson KC, Munshi NC (2006) Specific killing of multiple myeloma cells 
by (-)-epigallocatechin-3-gallate extracted from green tea: biologic activity and therapeutic implications. Blood 108: 2804-2810.

Tice RR, Andrews PW, Hirai O, Singh NP (1991) The single cell gel (SCG) assay: an electrophoretic technique for the detection of DNA damage in individual cells. Adv Exp Med Biol 283: 157-164.

Turner SD, Wijnhoven SWP, Tinwell H, Lashford LS, Rafferty JA, Ashby J, Vrieling H and Fairbairn LJ (2001) Assays to predict the genotoxicity of the chromosomal mutagen etoposide - focusing on the best assay. Mutation Res 493: 139-147.

Vlasova II, Feng WH, Goff JP, Giorgianni A, Do D, Gollin SM, Lewis DW, Kagan VE, Yalowich JC (2011) Myeloperoxidase-dependent oxidation of etoposide in human myeloid progenitor CD34+ cells. Mol Pharmacol 79: 479-487.

Whitlock JA, Greer JP, Lukens JN (1991) Epipodophyllotoxinrelated leukemia. Identification of a new subset of secondary leukemia. Cancer 68: 600-604.
Wilms LC, Hollman PCH, Boots AW, Kleinjans JCS (2005) Protection by quercetin and quercetin-rich fruit juice against induction of oxidative DNA damage and formation of BPDE-DNA adducts in human lymphocytes. Mutat Res 582: 155-162.

Zhou F, Zhang W, Wei Y, Zhou D, Su Z, Meng X, Hui L, Tian W (2007) The changes of oxidative stress and human 8-hydroxyguanine glycosylase 1 gene expression in depressive patients with acute leukemia. Lenkemia Res 31: 387-393.

Zhou FL, Zhang WG, Wei YC, Meng S, Bai GG, Wang BY, Yang HY, Tian W, Meng X, Zhang H, Chen SP (2010) Involvement of oxidative stress in the relapse of acute myeloid leukaemia. I Biol Chem 285: 15010-15015. 